\title{
OPUS DEI: BEYOND THE FICTION
}

\author{
Abi Makarim Hidayatullah, Lusia Kristiasih Dwi Purnomosasi \\ Department of English Teaching \\ Faculty of Letters and Arts Education IKIP PGRI Madiun \\ crew_1922@yahoo.com lusiakdp@gmail.com
}

\begin{abstract}
The purpose of this research is to describe the Opus Dei organization inside The Da Vinci Code movie and Opus Dei in reality. It is due to the controversies and much efforts to defend the truth against the movie. This research uses descriptive qualitative method. The researcher needs a sociology of literature by Alan Swingewood to get evidences the effect and goals of the author in creating a story. The analysis reveals that the representation of Opus Dei inside The Da Vinci Code confirms as dangerous organization, destructive mission, a killer, and corrupted members. It is contradiction facts far from reality that Opus Dei concerns on the serving people to keep devotion of Christian. Opus Dei is the open legal organization doing charity for better living which has mission and independent finance sources. The conclusion show that the controversies functions to get the movie's rating raised since it deals with the mass demand in popular literature. The evidences confirm that the representation of Opus Dei inside The Da Vinci Code are negated from the reality.
\end{abstract}

Keywords: Opus Dei, Sociology of Literature

\section{Introduction}

The Da Vinci Code is a mystery and thriller movie released at 19 May 2006 in United States of America directed by Ron Howard and Tom Hanks based on the novel The Da Vinci Code by Dan Brown. In the website IMDb http://www.imdb.com/ title/tt0382625/ the movie itself earns $\$ 217.536 .138$ from box office on 18 August 2006 in USA with the movie budget only $\$ 125.000 .000$. The Da Vinci Code movie gain its enormous popularity because of Howard's assertion of Mary Magdalene's marriage to Jesus Christ and the legend of the Holy Grail. There also represents that Jesus Christ has a blood line from his marriage to Mary Magdalene. Howard in The Da Vinci Code also brings story that there is endless war between the Guardian of the Holy Grail (Priory of Sion) and Council of Shadow that Opus Dei is one of the Council of Shadow member. It will be in mind that the popularity of this movie is mostly condemned by the society by reasons. It will be interesting to analyze further.

The researcher brings one of Catholic organization called Opus Dei because the movie unfairly shows Opus Dei. The followings are the evidences. Biondich (2007: 13) responds upon the popularity that Opus 
Dei insisted on itself to defend the reputation attacked by the movie. Opus Dei also got efforts to solidify among partners to send message to the media the real Opus Dei. Opus Dei begin their campaign against Brown after the movie was released, three years after the book was published. However, instead of attacking Brown and Sony Pictures, Opus Dei chose to inform the public about the real Opus Dei. According to this article Opus Dei became the victim in making of this movie because The Da Vinci Code always attacking Opus Dei and make a bad reputation of this organization. The way The Da Vinci Code represents Opus Dei inside the movie emerging wrath to the Catholic followers specially Opus Dei members and Catholic Church all around the world. Thus, the researcher is curious to see facts in both movie and reality to find out what controversies of Opus Dei are.

To go with the problem, the researcher will do with the sociology of literature by Allan Swingewood. He writes that,

... sociology is essentially the scientific, objective study of man in society, the study of social institutions and of social processes; it seeks to answer the question of how society is posible, how is works, why it persists.

Swingewood (1972: 11)

It means to study the social institution the researcher needs to study of how the society is created in the first place, what function, and why the society exist. By studying the social institutions and the social processes of Opus Dei, the researcher also gives a proof that literary work is still influenced the reality, as Swingewood explains,

... The most popular perspective adopts the documentary aspect of literature arguing that it provides a mirror to the age.

(1972: 13)

The explanation refers on how the works of fiction is actually a reflection from the age. Swingewood also explains that,

... it is interesting to note that on this point most sociologists of literature and literary critics are agreed: one studies great writers and their text precisely because their greatness implies deep insight into human and the social condition.

(1972: 22)

It means that author of the literature should understand on what condition in society before creating a work of literature. The author studies about society and history therefore literature is accepted by readers. Yet, the market demand and commercial business seem to flow a work of literature not to be the affirmation but negation toward the fact in society. That situation happens to the novel and movie of Opus Dei as stated by the above data. Based on the reason, there will be worthwhile to conduct the research on Opus Dei beyond the fiction as the response on the movies controversies.

\section{Method}

The researcher uses descriptive qualitative methods because of the research 
describes the representation between movie and reality. In qualitative research to begin the study the researcher gets data of the primary data and secondary data (Kothari, 2004: 95 and 111) concerning on movie of The $D a$ Vinci Code and resources such as journal, web, or article related to the existence of Opus Dei in The Da Vinci Code movie and reality, Catholicism. This research takes documentation as data collection methods because this research is qualitative research especially literary research (Berg, 2001: 3).The researcher collects the data through historical analysis, document, and textual analysis investigating the text from the article and books about Opus Dei. This study uses a content analysis because the data form of text or literary document (Berg, 2001: 240).

\section{Result}

To begin with the primary data, the following is the portrayal of Opus Dei in the movie. The distinguishing events will be several ones; monk of Opus Dei, organization of Opus Dei, the secret society of Opus Dei, and rituals corporal of Opus Dei. It is necessary to identify the description of Opus Dei in the movie to see how it is presented in the picture in order to get discussion on the real Opus Dei.

Opus Dei in the very beginning of The Da Vinci Code movie appears in Louvre Grand Gallery Paris. There was a man running in fear because somebody was chasing him. Then the man who ran pulling one of the painting in Grand Gallery in order to the security door could be closed for the man who ran after him. It did not work. Unfortunately, the man who chased pointed a gun. Later it figures out that the man who ran in fear was Jacques Sauniere (Jean Pierre Marielle), the grand master of Priory Sion, and the one who went after him was Silas, the Opus Dei's monk. Silas was on secret duty to get the cryptex whatever it took by his master's order.

The Da Vinci Code movie also represents Opus Dei rituals corporal mortifications. The primary data show after having conversation with the teacher Silas removed his clothes until got naked and showed his body full with whip scars and a cilice in his left thigh. This scene shows that Silas moved the cilice in his left thigh to his right thigh then he pulled it very hard until his right thigh got bleeding. Cilice is a spiked metal band worn around the thigh for two hours each day. Then, Silas whip himself with discipline, as a part of the corporal mortifications. Discipline is a cordlike whip. During Silas corporal mortifications, he faced the Cross and spoke to the Cross in France which means in English he chastised his body.

The Opus Dei in The Da Vinci Code movie is not the only one who goes after the Holy Grail. It is actually the Council of 
Shadow who goes after the Holy Grail in order to destroy it. The destroying evidence aims to show no proof of the living bloodline of Jesus Christ. Bishop Aringarosa from Opus Dei was one of the members in the Council of Shadow. It appears clearly that Opus Dei has an enemy which both of Opus Dei and its enemy get the same mission for chasing Holy Grail.

Opus Dei is the secret society which does brain washing and is of ultraconservative Catholic in The Da Vinci Code movie. In the conversation inside the private jet between Bishop Aringarosa and Michael, an Opus Dei journalist, that he denied the accusation questions from Michael about Opus Dei as a brain washing agency and as Catholic secret ultraconservative society. He claimed that Opus Dei was only the simple Catholic Church. Michael was in doubt about Aringarosa's answer because Opus Dei had headquarter in Manhattan with budget $\$ 47$ million. This point in The Da Vinci Code shows that Opus Dei got their budget from member's donation. The movie represents Opus Dei did brain washing to their members to make them willing to donate their earnings for Opus Dei. It is also proven by the member of this fraternity who would do everything as long as it is commanded by Opus Dei without questioning the consequences of what they have done.

\section{Discussion}

To understand the existence of Opus Dei, the study of the history on how Opus Dei found is needed (Swingewood, 1972: 11). The discussion will start identifying what Opus Dei is. The necessary historical data are as follows. It is about the founding father of Opus Dei by Escriva (Cummings, 1976: 539). In 9th January 1902 Josemaría Escrivá de Balaguer was born in small town Barbastro in Spain. Latter when he grew up Escriva became the future founder of The Catholic Prelature of Opus Dei and Holy Cross and also future saint of the Holy Catholic Church. Escriva developed Opus Dei as the organization to support Church operation and services. It is further data in Condon's journal (1957: 106). It explains that Opus Dei is the secular organization. As the first secular institutes in the Catholic Church, Opus Dei helps people to find Opus Dei in daily life or continuing works of Opus Dei. Escriva used to say that God had already opened up before his eyes the God's works. He figured it out that God really wanted him as the one who gave service to the universal Church and Christian people souls. The main idea of Escriva developing Opus Dei was to sanctification Catholic people using Holly Bible teachings and Catholic Church accurate teachings then spread it to everyone in the world. The researcher comes to the result that Opus Dei is 
the organization with concrete mission. Helping people around the world is the important thing for each member.

The organization has its symbol. Such obligation represents in the symbol of cross within the circle. It means Opus Dei's members have to oblige to spread the Bible and Catholicism around the world (Cummings, 1976: 539; Allen, 2005: 23). Concerning with it, the movie of The Da Vinci Code shows the symbol of cross within the circle appears when Robert Langdon (Tom Hanks) and Captain Bizu Fache (Jean Reno) were entering the elevator of Grand Gallery in Louvre, Paris. Langdon saw the symbol of the cross in Fache's coat. Another data show in Sir Leigh Teabing's (Ian McKellen) house when Langdon, Leigh, and Sophie Neveu (Audrey Tautou) discussed about cryptex mystery while suddenly unwelcome guest Silas (Paul Bettany), the Opus Dei's monk, got in interrupting and tried to take the cryptex by force. The movie reveals that Opus Dei is a secret organization and gets mission to chase the Holy Grail while the secondary data show that Opus Dei is the official organization of the Church and helps people. It is the contradictory fact between Opus Dei in the movie and the reality.

Another fact in the movie retrieved from the data previously speaks to the audience that Silas is as Opus Dei's monk.
These data reveal that Opus Dei has monks which is also described in the result previously. This monk gets conflict against another organization, Priory Sion. In line with the primary data of the existence of Opus Dei's monk, it is data taken from the documentary video which talk about it. It is directed and written by George Tzimopoulus entitled Opus Dei. He shows that Opus Dei has no monks or nuns but the clergy inside the Opus Dei are Priest, Bishop, and Cardinals. This information is supported by official website of the Opus Dei in http://opusdei.us/en-us/article/the-da-vincicode-the-catholic-church-and-opus-ei/ that Opus Dei has no monks. Therefore, the researcher confirms that the existence of Silas as an Opus Dei's monk is not true. It is made up by the script writer to certain intention.

The differences between the fiction and the reality on Opus Dei continues to the next issue, the mission. Considering on the primary data of Opus Dei as the Church organization stated in the result, Swingewood in his theory mentions that to understand the organization or society need to learn about how the society works (1972: 11). The followings are the secondary data describing what the Opus Dei really is and how it deals with the mission.

Opus Dei as the organization has its own role in the church. It is quiet open and 
public organization. The article of Helming (1973: 402) states that Opus Dei comes into exist for anyone who took seriously to choose a single Catholic view and to give them an answer or solution about most general problem in life. Opus Dei believed that it can provide the answer and solution for anyone from questions such as economic, politic, and social problem. Opus Dei contributes to the Catholic Church to be evangelism to all of the Christian. Opus Dei had a mission to spread a spiritual advice and instruction to everyone although not a member of the Opus Dei. The researcher sees that the statements refer to the counter description upon the organization of Opus Dei that it belongs to everyone needs help.

Muller's article confirms the statement of Helming as the following. This article explains that Opus Dei has a contribution to the Catholic Church promoting among Christian from all the social classes to be fully devoted and believe in their faith as the Christian. Opus Dei also has to sanctify Christian in their circumstances in their lives and their work no matter what it is. Another secondary data also explains in the official website of Opus Dei as McClelland's. The main contribution of Opus Dei is to give the Church and the society any necessary helps to people. Opus Dei advices people to seek God within personal experience in daily life through relationship with others, families, schools, and in labor. The purpose of Opus Dei based on the documentary video Opus Dei Unveiled Opus Dei teach their members to find or to had a relationship with God not just in Sunday which is a day mostly Christian Catholic used to pray, but in everyday life in every moment and every circumstances. The researcher confirms that Opus Dei is not the secret organization. There are mission on helping people to see God in the daily life even in the simple one. It means a lot to Christian to be the representation from what God says in the Bible. This fact contradicts with the images from the movie that it is an inclusive organization.

Besides, the open recruitment of Opus Dei members is publicly open for people. This is another evidence that Opus Dei is not secret. For supporting the idea, the researcher quotes from Coverdale (1934) who writes in his article about the way applying for the member of Opus Dei. Until 1935, seventh years after the Opus Dei was founded by Escriva, to become the member of Opus Dei was simply by asking Escriva to be admitted. In the case of a new comer, a civil engineering named Alvaro del Portillo who wanted to become the member of Opus Dei, Escriva asked him to write a letter to be admitted. This point shows how people should do to join Opus Dei. Coverdale continues to describe the condition 
of the new member. He observes that in early years in Opus Dei was only about to do God's works. It was still unspecific job to be sanctified person. Later, the members of Opus Dei involved in the educational program in the United Stated at Midtown and Metro Centers. It is confirmed in Opus Dei official website in http://opusdei.us/en-us/article/history-andactivities which explains that members of Opus Dei assist to the underprivileged program. Opus Dei helped thousands of African-American and Hispanic youth in the downtown of Chicago. It was around $95 \%$ of the students at Midtown and Metro graduated from high schools, and $89 \%$ among them go on to college. There the same programs of the Opus Dei exist in the South Bronx section of New York and in Washington, D.C. The researcher sees the important position of Opus Dei among society to get young people get well educated opportunity.

Those data convince the researcher that there will be a continuing action of Opus Dei in doing charity and giving helps. It means Opus Dei persists to be around the people. There is a reason why the organization still exist. The researcher will provide the secondary data to see it. Coverdale (1934) states in the couple months after the Opus Dei was found, at 02 October 1928, Escriva summoned a meeting with the potential members of Opus Dei and explained about what he planned to sanctify the world. Escriva encouraged the entire potential member of Opus Dei to come to him for a spiritual direction. Escriva only explained to the potential members of Opus Dei about he was ideal of sanctity the world and apostolate in the middle of the world through work done conscientiously and for love of God.

The researcher finds that Opus Dei is a kind of volunteer program for young people. Since then, Opus Dei publishes the names to the international and regional directors. Like article in the official website of Opus Dei (http://opusdei.us/en-us/article/opus-dei-factand-fiction/) explain that, Opus Dei is not a secret society. Like dioceses and parishes Opus Dei does not publish its member's names neither like in the health people deserve as much as privacy in their spiritual affairs as in the medical matters. It is due to Opus Dei protects their member's privacy not because Opus Dei is a secret organization. In fact the members of Opus Dei happily tell everyone else that they are member of the Opus Dei and explain about what Opus Dei really is. This is the confirmation from those data that Opus Dei works in social and religious activity for people.

To go with the mission of Opus Dei, it needs cost. The donation for supporting mission comes from the charity. The following is the data concerning with donation. Opus 
Dei financed their operation from everyone who still concern about Opus Dei without asking them, as Coverdale (1934) explains in Piatkowski's thesis. Opus Dei got the finance source from anyone not only the Opus Dei members, rather anyone who still had concern to Opus Dei development. It is not the same as The Da Vinci Code represent in the movie about Opus Dei. Opus Dei got its finance only by its members like Aringarosa used to do.

Opus Dei does no harm but virtue. That is why, to become the member there will be no brain washing. The official website of Opus Dei in the article (http://opusdei.us/enus/article/opus-dei-fact-and-fiction/) explains that Opus Dei completely respects for people freedom. The researcher argues that it is unreasonable to assume that the Pope and Bishops would support an institution that practicing a brainwashes practice. Opus Dei helps people grow their faith and practicing it in their daily life. These reality say different from the movie. The Da Vinci Code movie represents Opus Dei's relation to its member. To accomplished personal interest the Bishop of Opus Dei, Aringarosa gave an unreasonable command to its member, Fache, who accepting the command to catch Langdon for accusing murderer for four people without any evidences. Fache was afraid of accusing as betrayer if he did not do as the Bishop's order. Above all, he will make God disappointed for his services. Those are contradiction for what the movie shows and statement that Opus Dei respect for people freedom.

Chasing people for murdering him and doing the painful ritual in the movie seem to be the next discussion. Doing harm is done to gain the goals of Opus Dei based on the Bishop order. The researcher provides the secondary data to analyze that facts in movie. The purpose of Opus Dei based on the documentary video Opus Dei Unveiled, Opus Dei teaches their members to find or to have a relationship with God not just in Sunday which is a day mostly Christian Catholic used to pray, but in everyday life in every moments and every circumstances where Opus Dei members join. From this data, the researcher assumes that getting bond by God is the spirituality of Opus Dei. It is supported by another secondary data which shows that the Catholic Church teaches no one should ever do evil to others, even for a good purpose. Article in the official website of the Opus Dei (http://opusdei.us/en-us/article/the-da-vincicode-the-catholic-church-and-opus-ei/) explains that Opus Dei never do a murdering, lying, drugging people, and otherwise acting unethically for the sake of God, the Catholic Church, even for Opus Dei itself. Opus Dei as the Catholic institution has a mission to help people integrate their faith in Christianity and their activities of their daily life. It also helps 
people for their spiritual education and counseling and helps members to be more ethical. Those facts in the data confirm that the fact in movie tells no truth about Opus Dei.

\section{Conclusion}

Opus Dei becomes the most controversial organization in the world since The Da Vinci Code novel by Dan Brown was published, and two years after the novel published, in the same title The Da Vinci Code movie released directed by Ron Howard, again the movie represented the Opus Dei as controversial organization. The movie attempts to present Opus Dei as something negative, destructive, dangerous, and bad image. In reality Opus Dei is a humble organization of the Catholic Church. It is rather exclusive institution which open for everyone to give helps. This organization does no harm and no any rituals for the members. It also gets cost by charity from people. Opus Dei denied all the accusation that represented in the movie.

The movie delivering controversies proves that the creation process of the author is making up the reality to be eagerly consumed by the audience. It is supported by Swingewood (1972: 43-48). The mass consumption will be the clue to see the transformation from novel into movie because it is engaged by popular literature in the popular culture. The controversies deal with the market and commercial to provide sensation. Such reaction on the movie is simply the mass response to rise the rating. There must be reason why Howard creates controversies in his works, but this research relies on describing the controversies between Opus Dei in movie and reality. In short, the performance of Opus Dei goes to the negation from the reality. For the effect, Opus Dei is noticed as the tough secular secret organization of Church and The Da Vinci Code gets the attention of the audience to see more about Opus Dei in the movie.

\section{Acknowledgements}

The researcher would like to gratitude to the following persons: Mr. Hadiningrat, Mr. Wasito, Danik, Meriana, Novi, and Sintia. Those are soul mates during the process.

\section{References}

Allen, John L. 2005. OPUS DEI: an Objective Look behind the Myths and Realty of the Most Controversial Force in the Catholic Church. New York: Penguin Group.

Berg, Bruce L. 2001. Qualitative Research Method for the Social Sciences Fourth Edition. Boston: A Pearson Education Company.

Biondich, Kirsten. 2007. Operation Lemonade: Opus Dei's Public Relations Campaign against The Da Vinci Code (Online). (http://ufdcimages.uflib. 
ufl.edu/UF/E0/02/10/07/00001/biondic

h_k.pdf. Download: 30/10/2013 09:00).

Condon, James. 1957. The Secular Institutes and the Opus Dei. Studies: An Irish

Quarterly Review (Online), Vol. 46, No. 181: 106-108, (http://www.jstor.org. Stble/3098861. Download: 22/03/2104 09:47)

Coverdale, John. 1934: Revolution in Spain

(Online).(http://www.josemariaecri va.info/article/documntation-1934revolutionin-spain, Accessed at 13January 2015).

Cummings, Daniel. 1976. The Founder of Opus Dei. The Furrow (Online), Vol. 27, No. 9 : 539-542, (http://www.jstororg/stble/27660212. Download: 22/03/2104 09:47).

IMDb. The Da Vinci Code (Online). (http://www.imdb.comtle/tt02625,

Accessed at 16 January 2014).

Jose Maria Info. Any questions about Opus Dei? (Online). (http://www.josemariae scriva.info/article/opus-dei-foundersaint-josemaria-escriva-answers-questi ons-about-opus-dei, Accessed at 08 January 2015).

Kothari, C R. 2006. Research Methodology. New Delhi: New Age International.
McClelland, Alan. What Opus Dei can Contribute to Present-Day Church and Society (Online). (http://www.opusdei.org.uk/enuk/article/what-opus-dei-can-contributeto-present-day-church-and-society, Accessed at 08 January 2015)

Opus Dei Organization. Activities (Online). (http://opusdei.us/enus/article/activities, Accessed at 08 January)

Opus Dei Organization. 2008. History and Activities.(Online). (http://opusdei.us/enus/article/history-and-activities, Accessed at 08 January 2015).

Opus Dei Organization. 2004. Opus. Dei: Fact and Fiction. (Online). (http://opus dei.us/en-us/article/opus-dei-fact-andfiction, Accessed at 08 January 2015).

Opus Dei Organization. 2004. The Da Vinci Code, the Catholic Church and Opus Dei (Online). (http://opusdei.us/enus/article/the-da-vinci-code-thecatholicchurch-and-opus-dei, Accessed at 08 January 2015).

Opus Dei Organization. 2002. What is Opus Dei? (Online). (http://opusdei.us/en us/article/what-is-opus-dei, Accessed at 08 January 2015).

Opus Dei Organization. Questions (Online). (http://www.opusdei.org/en-us/faq, Accessed at 08 January 2015).

Piątkowski, Przemysław. 2009. The Work of God: An Ethnography Of Opus Dei,

(Online). (Download from: http://www.kostera.pl/documents/Przemek.pdf Download: $\quad$ 06/03/2014 12.54) 
Swingewood, Alan. 1972. The Sociology of Literature. New York: Paladin.

Tzimopoulos, George. Opus Dei Unveiled (Online). (https://www.youtube.com/ watch?v=DM2DLC_8eTA, Download at 09 November 2014). 